\title{
Relationship between Soil Management Methods and Soil Chemical Properties in Protected Cultivation
}

\author{
Yun-Im Kang ${ }^{1)^{*}}$, In-Bog Lee ${ }^{2)}$, Jin-Myeon Park ${ }^{2)}$, Yong-Gu Kang ${ }^{2)}$, Seung-Heui Kim²), \\ Hyeon Seok $\mathrm{Ko}^{3)}$, and Joon Kook Kwon ${ }^{1)}$ \\ ${ }^{1)}$ Protected Horticulture Research Station, National Institute of Horticultural and Herbal Science, \\ Rural Development Administration, Busan 618-800, Korea \\ ${ }^{2)}$ National Institute of Horticultural and Herbal Science, Rural Development Administration, Suwon 440-760, Korea \\ ${ }^{3)}$ Knowledge \& Information Officer, Rural Development Administration, Suwon 441-707, Korea
}

(Received December 9, 2009, Accepted December 20, 2009)

\begin{abstract}
Various cultural practices have been promoted as management options for enhancing soil quality and health. The use of soil management methods can cause changes in fertility by affecting soil chemical properties. This study aimed to evaluate interactions between soil chemical properties and soil management methods in protected cultivation, and to classify soil management methods that similarly affect soil chemical properties. Water-logging and irrigation reduced soil $\mathrm{pH}$ and available $\mathrm{P}_{2} \mathrm{O}_{5}$ content. Application of animal manures has a positive effect on levels of organic matter, $\mathrm{Av}_{\mathbf{2}} \mathrm{P}_{2} \mathrm{O}_{5}, \mathrm{~K}, \mathrm{Zn}$, and $\mathrm{Cu}$. The electrical conductivites tened to be low in the application of organic amendments, including rice and wood residues. Deeper plowing caused a reduction in Ca content. Practicing soil nutrient-considering fertilization and fertigation did not exert an influence on nutrient element contents. In a cluster analysis of the soil management methods according to major nutrients, low similarities were found with deeper plowing and crop rotation with rice in comparison with other practices. In a cluster analysis by minor nutrient characteristics, crop rotation and application of animal manures and rice residues were linked at a high Ward's distance, while other practices were found to be relatively low distinct. Each soil management method has a similar or different effect on soil chemical properties. These results suggest the necessity of establishing limits and standards according to the effects of soil management methods on soil chemical properties for economic soil practices.
\end{abstract}

Key Words: Cluster analysis, Protected cultivation, Continuous cropping, Soil chemical property, Soil management

\section{INTRODUCTION}

Various agricultural practices, including the use of cover and rotational crops, composts, tillage systems, and others have been promoted as management options for enhancing soil quality and health ${ }^{1)}$. For successful protected cultivation, the importance of soil management methods has been recognized ${ }^{2}$. The use of soil management methods can cause changes in fertility by affecting physical and chemical properties

*연락저자:

Tel: +82 51602 2133; Fax: +82 519712024

E-Mail: yunimy@korea.kr of soil and the activity of soil microbes. Soil chemical properties determine the ability of the soil to enhance crop production. Soil total $\mathrm{N}$, soil organic matter, N, P, $\mathrm{K}$, soil $\mathrm{pH}$, and electrical conductivity $(\mathrm{EC})$ are important measurements for assessing the chemical aspects of soil quality $^{3)}$. These management methods decisions include a multiplicity of methods, such as crop rotation, residue management, leaching by irrigation, and application of manures.

Maintaining or improving soil quality can provide economic benefits in the form of increased productivity, more efficient use of nutrients and pesticides, improvements in water and air quality, and amelioration of 
greenhouse gas emissions ${ }^{4)}$. Soil management methods create inefficiencies by over-treating or under-treating portions of a field, increasing field management costs and decreasing net economic returns ${ }^{5)}$. This study evaluated the correlation of each soil chemical properties and the interactions between soil chemical properties and soil management methods in protected cultivation. The study also classifed soil management methods according to similar influences on soil chemical properties.

\section{MATERIALS AND METHODS}

\section{Soil management survey}

Data was collected during 2006 and surveyed 25 farms in main fruit vegetables production locations in Korea. The locations were Iksan, Nonsan, Suncheon, Gurye, Andong, Buyeo, Haman, Seongju, Jinju, and Cheongju. Soil management methods were investigated by qualitative interviews with farmers. The farmers were asked whether or not they rotated their crops excluding rice, performed soil nutrient-considering fertilization, practiced deeper plowing, performed crop rotation with rice, practiced water-logging and irrigation, and whether or not they applied rice residues, wood residues, animal manures, and practiced fertigation.

\section{Soil sampling and analysis}

Soil samples were collected with the soil management methods survey at once and were comprised of ten soil sub-samples from each farm. The soil subsamples excluded topsoil (3 cm depths) and were collected at $20 \mathrm{~cm}$ depths using an auger. The subsamples were mixed and then were dried by air under the shade and sieved through a $2 \mathrm{~mm}$ sieve before analysis. Detailed descriptions of the methods used for soil chemical analyses are given by NIAST ${ }^{6}$. Phosphate (P) contents were estimated using the chlorostannous molybdophosphoric blue-color method, in sulfuric acid. Total organic matter (OM) was determined by the bichromate oxidation method by Tyurin. The concentrations of calcium $(\mathrm{Ca})$, magnesium $(\mathrm{Mg})$, potassium $(\mathrm{K})$, zinc $(\mathrm{Zn})$, iron $(\mathrm{Fe})$, manganese $(\mathrm{Mn})$, and copper $(\mathrm{Cu})$ were determined through ICP (GBC, Integra XMP, Australia). EC (1:5 soil/water) was measured with an electrical conductance meter (CM-30R, DKK-TOA, Japan) and the $\mathrm{pH}$ (1:5 soil/water) was measured with a $\mathrm{pH}$ meter (720A, Orion, USA).

\section{Statistical analysis}

Correlation analysis was used to analyze chemical properties of greenhouse soil. Effects of soil management methods on each soil chemical properties were analyzed by GLM procedures. Effects of soil management methods on major element $(\mathrm{P}, \mathrm{K}, \mathrm{Ca}$, and $\mathrm{Mg})$ and minor element $(\mathrm{Fe}, \mathrm{Mn}, \mathrm{Zn}$, and $\mathrm{Cu}$ ) properties were analyzed by cluster analysis using Ward's minimumvariance. Cluster analysis was performed based on selected first principal components of elements. Selection of the first component of each major and minor element was performed by the correlation matrix. The analysis was computed by SAS 9.0.

\section{RESULTS}

The soil chemical properties of farms surveyed are presented in Table 1. The soil $\mathrm{pH}$ values of the farms varied from 7.78 to 5.18. The nutrient contents also showed enormous differences among the farms. The farms cumulatively practiced several soil management methods for sustaining soil productivity, including crop rotation excluding rice, soil nutrient-considering fertilization, deeper plowing, crop rotation with rice, waterlogging and irrigation for salt removal, application of rice residues, application of wood residues, application of animal manures, and fertigation (Table 2). Although the soil characteristics of farms had enormous differences, The significant correlations exhibited among soil chemical properties. (Table 3). Organic matter was significantly

Table 1. Summary of soil chemical properties in surveyed 25 farms

\begin{tabular}{|c|c|c|c|c|c|c|c|c|c|c|c|}
\hline & \multirow{2}{*}{$\begin{array}{c}\mathrm{pH} \\
(1: 5)\end{array}$} & \multirow{2}{*}{$\begin{array}{c}\mathrm{OM} \\
(\mathrm{g} / \mathrm{kg})\end{array}$} & \multirow{2}{*}{$\begin{array}{l}\mathrm{Av} \cdot \mathrm{P}_{2} \mathrm{O}_{5} \\
(\mathrm{mg} / \mathrm{kg})\end{array}$} & \multicolumn{3}{|c|}{--Ex. Cations (cmol/kg)-- } & \multicolumn{4}{|c|}{ - } & \multirow{2}{*}{$\begin{array}{c}\mathrm{EC} \\
(\mathrm{dS} / \mathrm{m})\end{array}$} \\
\hline & & & & $\mathrm{K}$ & $\mathrm{Ca}$ & $\mathrm{Mg}$ & $\mathrm{Fe}$ & $\mathrm{Mn}$ & $\mathrm{Zn}$ & $\mathrm{Cu}$ & \\
\hline Max. & 7.78 & 5.28 & 2451.39 & 4.05 & 22.59 & 9.36 & 368.29 & 79.79 & 61.04 & 21.89 & 11.65 \\
\hline Min. & 5.18 & 1.43 & 219.88 & 0.28 & 4.84 & 1.46 & 1.07 & 4.20 & 2.13 & 0.86 & 0.70 \\
\hline Mean & 6.76 & 3.32 & 1121.97 & 1.69 & 10.79 & 3.50 & 110.94 & 24.00 & 17.08 & 7.34 & 3.72 \\
\hline
\end{tabular}


Table 2. Practice soil management methods to avoid continuous cropping injuries in surveyed 25 farms

\begin{tabular}{lc}
\hline \multicolumn{1}{c}{ Soil management methods } & Numbers using the methods in all farms \\
\hline Crop rotation excluding rice & 6 \\
Soil nutrient-considering fertilization & 21 \\
Deeper plowing & 9 \\
Crop rotation with rice & 3 \\
Water-logging and irrigation & 13 \\
Application of rice residues & 12 \\
Application of wood residues & 12 \\
Application of animal manures & 18 \\
Fertigation & 17 \\
\hline
\end{tabular}

Table 3. Correlation matrix of soil chemical properties of 25 farms

\begin{tabular}{|c|c|c|c|c|c|c|c|c|c|c|c|}
\hline & $\mathrm{pH}$ & $\mathrm{OM}$ & Av.P2O5 & $\mathrm{K}$ & $\mathrm{Ca}$ & $\mathrm{Mg}$ & $\mathrm{Fe}$ & Mn & $\mathrm{Zn}$ & $\mathrm{Cu}$ & EC \\
\hline $\mathrm{pH}$ & - & & & & & & & & & & \\
\hline $\mathrm{OM}$ & 0.052 & - & & & & & & & & & \\
\hline Av. $\mathrm{P}_{2} \mathrm{O}_{5}$ & 0.278 & $0.521^{* *}$ & - & & & & & & & & \\
\hline K & 0.162 & $0.474^{*}$ & $0.427 *$ & - & & & & & & & \\
\hline $\mathrm{Ca}$ & 0.181 & 0.177 & 0.198 & $0.568^{* *}$ & - & & & & & & \\
\hline $\mathrm{Mg}$ & 0.350 & 0.093 & $0.420 *$ & $0.511^{* *}$ & $0.792^{* * *}$ & - & & & & & \\
\hline $\mathrm{Fe}$ & -0.257 & 0.362 & $-0.412^{*}$ & 0.003 & -0.017 & -0.328 & - & & & & \\
\hline Mn & 0.148 & 0.197 & 0.070 & 0.028 & -0.014 & -0.006 & 0.374 & - & & & \\
\hline $\mathrm{Zn}$ & -0.035 & $0.686^{* * *}$ & $0.579^{* *}$ & $0.563^{* *}$ & 0.039 & -0.057 & 0.153 & 0.077 & - & & \\
\hline $\mathrm{Cu}$ & -0.066 & $0.532^{* *}$ & $0.596^{* *}$ & $0.440^{*}$ & 0.119 & 0.099 & 0.211 & 0.280 & $0.811^{* * *}$ & - & \\
\hline $\mathrm{EC}$ & -0.265 & -0.142 & 0.038 & 0.300 & $0.528^{* *}$ & $0.537^{* *}$ & -0.276 & -0.290 & -0.140 & -0.014 & - \\
\hline
\end{tabular}

$*, * *$ and ${ }^{* * *}$ significant at $\mathrm{p}<0.05,0.01$, and 0.001 , respectively.

correlated with Av. $\mathrm{P}_{2} \mathrm{O}_{5}, \mathrm{~K}, \mathrm{Zn}$, and $\mathrm{Cu}$. High correlations were found among $\mathrm{K}, \mathrm{Ca}$, and $\mathrm{Mg}$. EC increased as contents of $\mathrm{Ca}$ and $\mathrm{Mg}$ increased.

The soil management methods influenced the soil chemical properties (Table 4). The soil chemical properties did not change individually. Standardized estimate mean was used to numerically evaluate relative influence. Water-logging and irrigation decreased $\mathrm{pH}(p<0.225)$ and Av. $\mathrm{P}_{2} \mathrm{O}_{5}(p<0.234)$, but increased $\mathrm{K}$ content $(p<0.065)$ in the soil. The application of animal manures had a positive effect on the organic matter $(p<0.014)$, Av. $\mathrm{P}_{2} \mathrm{O}_{5}(p<0.198), \mathrm{K}(p<0.065), \mathrm{Zn}(p<0.116)$, and $\mathrm{Cu}$ $(p<0.084)$. Crop rotation excluding rice increased $\mathrm{Mn}$ $(p<0.108)$, but did not influence other soil chemical properties. The ECs tended to be low following application of organic amendments; rice residues $(p<0.109)$ and wood residues $(p<0.068)$. Deeper plowing led to a reduction in $\mathrm{Ca}(p<0.032)$ content. The soil nutrientconsidering fertilization practice had no an influence on nutrient element contents. Practicing fertigation also did not affect nutrient element contents, but reduced EC $(p<0.149)$ in soil.

Fig. 1 and 2 show the similarities of the soil management method effects on soil major and minor nutrient elements, grouped by the amount of usage by plants. In cluster analysis of major nutrient of the soil management method effects, low similarities were found in deeper plowing and crop rotation with rice in comparison with other practices (Fig. 1). In minor nutrient characteristics, crop rotation and application of animal manures were closely linked at a high Ward's distance, while a distance among other practices were relatively low distance (Fig. 2). 
Table 4. Effects of soil management methods on the soil properties; Standard estimates using regression: $C R$ Crop rotation excluding rice, SC Soil nutrient-considering fertilization, DP Deeper plowing, CRR Crop rotation with rice, WI Water-logging and irrigation for salt removal, $A R$ Application of rice residues, $A W$ Application of wood residues, $A A$ Application of animal manures, $F$ Fertigation.

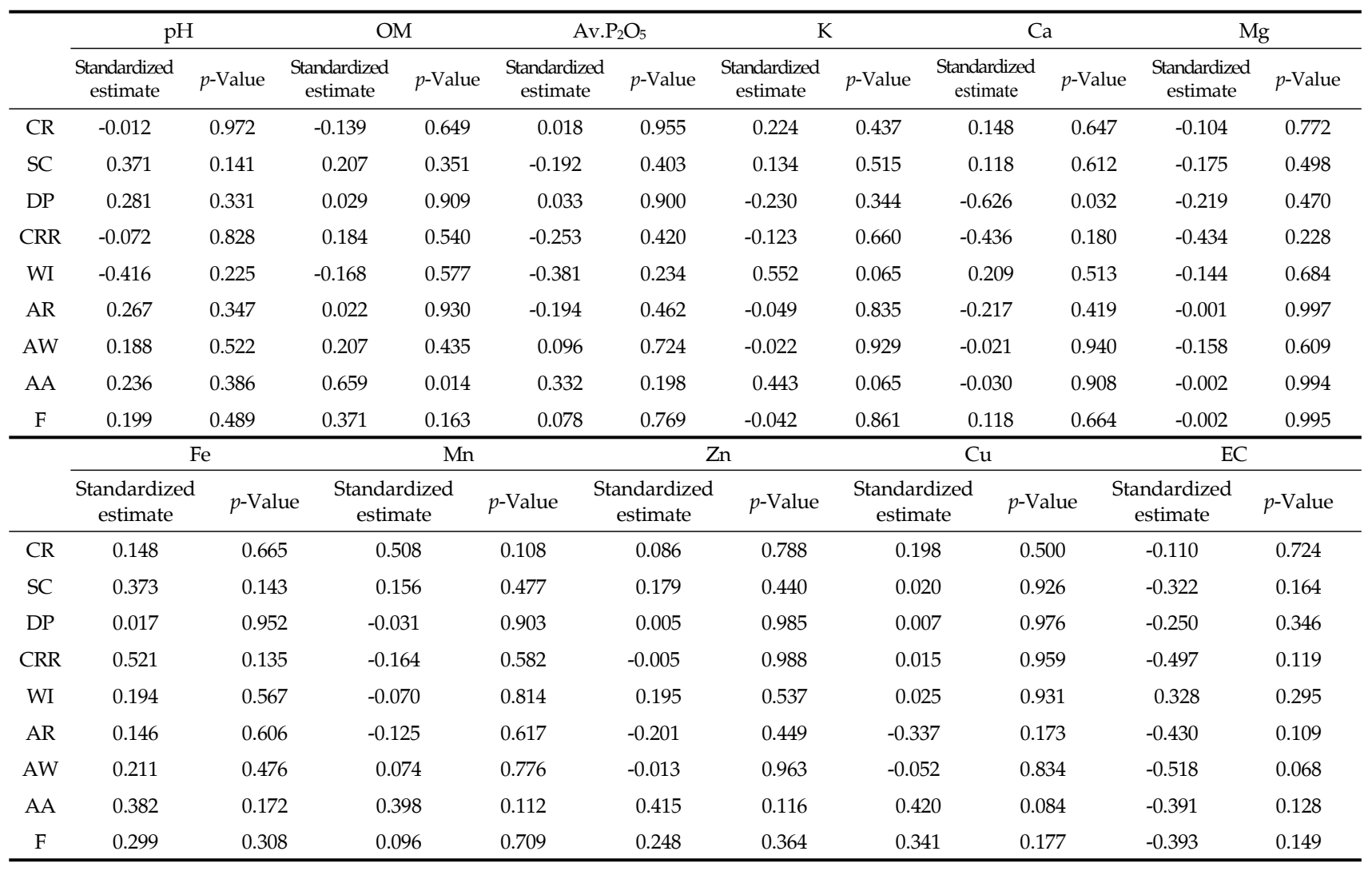

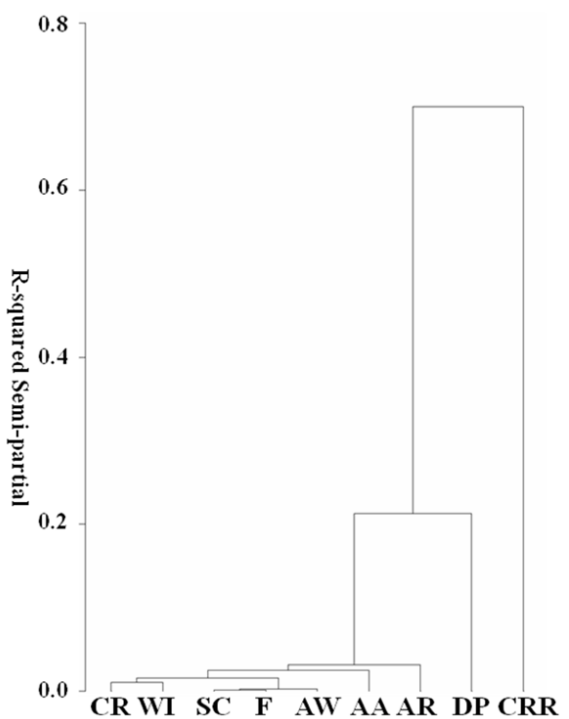

Fig. 1. Cluster analysis of major nutrient data of soil management methods: $C R$ Crop rotation excluding rice, $S C$ Soil nutrient-considering fertilization, DP Deeper plowing, CRR Crop rotation with rice, WI Water-logging and irrigation for salt removal, $A R$ Application of rice residues, $A W$ Application of wood residues, $A A$ Application of animal manures, $F$ Fertigation.

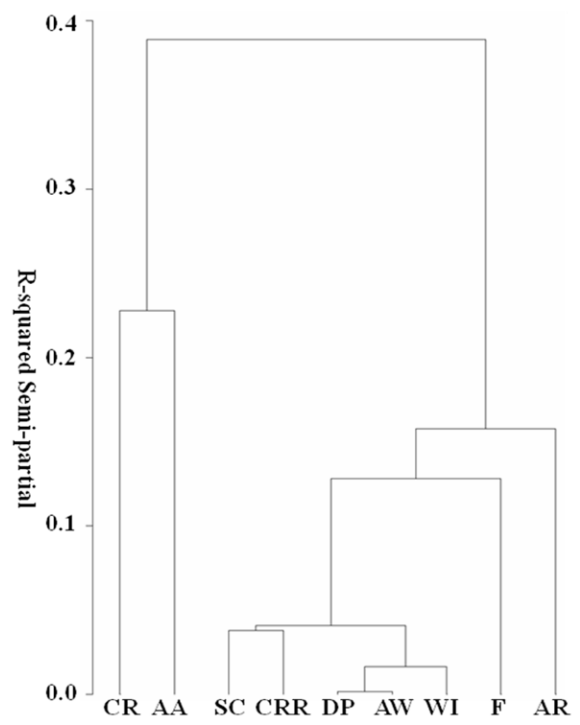

Fig. 2. Cluster analysis of minor nutrient data of soil management methods: $C R$ Crop rotation excluding rice, $S C$ Soil nutrient-considering fertilization, DP Deeper plowing, CRR Crop rotation with rice, WI Water-logging and irrigation for salt removal, $A R$ Application of rice residues, $A W$ Application of wood residues, $A A$ Application of animal manures, $F$ Fertigation. 


\section{DISCUSSION}

The contents of greenhouse soil nutrient in Korea are higher than those in open-field soils ${ }^{7}$. Although soil $\mathrm{pH}, \mathrm{EC}$, and organic matter content and nutrients were variable among farm soils surveyed (Table 1), the means of the soils were excessive compared to optical nutrient range for vegetable cultivation ${ }^{8)}$. Zhao et al. ${ }^{9)}$ and Bozkurt et al. ${ }^{10)}$ reported nutrient contents in protected vegetable land, which managed intensively, were higher than those in grain cropland. The characteristics of surveyed greenhouse soils showed that soil $\mathrm{pH}$ was negatively correlated with EC similar to Bozkurt et $\mathrm{al}^{\prime}$ s result ${ }^{10)}$ and Lee et $\mathrm{al}^{\prime}$ 's result ${ }^{11)}$, but not significant (Table 3). Organic matter content, a sensitive indicator of management effects on soil quality ${ }^{3)}$, had a highly positive correlation with Av. $\mathrm{P}_{2} \mathrm{O}_{5}$, $\mathrm{K}, \mathrm{Cu}$, and $\mathrm{Zn}$. Eighteen farms among the 25 farms practiced application of animal manures (Table 2), and this should cause increased Av. $\mathrm{P}_{2} \mathrm{O}_{5}$ and $\mathrm{K}$ in the soils. Application of animal manures, which have high contents of Av. $\mathrm{P}_{2} \mathrm{O}_{5}$ and $\mathrm{K}$, increased contents of Av. $\mathrm{P}_{2} \mathrm{O}_{5}$ and $\mathrm{K}$ in soils ${ }^{12,13)}$. Correlation between organic matter and $\mathrm{Zn}$ seem to be induced by the application of rice residues, which have large content of $\mathrm{Zn}$ and minor nutrients ${ }^{14)}$.

Available $\mathrm{P}_{2} \mathrm{O}_{5}$ was negatively correlated with Fe. The chemical nature and generally high specific surface area of the iron hydroxylated minerals make them efficient sinks for anions such as phosphate, so that iron and phosphorus deficiencies are often associated ${ }^{15)}$. High positive correlations among $\mathrm{K}, \mathrm{Ca}$, and $\mathrm{Mg}$ might result from application of major fertilizers elements used at the farms. Also, EC, related with total salt, ${ }^{10)}$ was significantly correlated with $\mathrm{Ca}$ and $\mathrm{Mg}$ in protected cultivation. These results show that farms in protected cultivation practice excessive fertilization of $\mathrm{Ca}, \mathrm{Mg}$, and $\mathrm{K}$.

Soil variability is the result both of natural processes and management practices ${ }^{5}$. In greenhouses, the covering materials do not allow rain to reach the soil surface. Therefore, the salt contents of greenhouse soils are much higher than those of the open-field soils $^{10,16)}$. Soil EC decreased with water-logging and irrigation. Practicing water-logging and irrigation reduced Av. $\mathrm{P}_{2} \mathrm{O}_{5}$ and soil $\mathrm{pH}$, but had no significant effect on changes of $\mathrm{Ca}$ and $\mathrm{Mg}$ contents in soil.
Application of animal manures had positive effects for organic matter, Av. $\mathrm{P}_{2} \mathrm{O}_{5}, \mathrm{~K}, \mathrm{Zn}$, and $\mathrm{Cu}$, and this result associated with Table 3's results.

DeMaria et al. ${ }^{17)}$ reported that crop rotation change soil chemical properties. Moreover, crop rotation increases microbial biomass and produced differing microbial community profiles in soils ${ }^{17,18)}$. In present study, effect of crop rotation excluding rice on $\mathrm{Mn}$ content in soil was observed. Because crop rotation lead to application of various organic matters, $\mathrm{Mn}$ content increase as well as $\mathrm{Zn}^{19)}$. Furthermore, crop rotation causes changes of soil chemical properties and results in the increment of exchangeable and extractable $\mathrm{Mn}^{20)}$.

Soil organic matter has been associated with numerous soil functions including nutrient cycling, water retention and drainage, erosion control, disease suppression and pollution remediation ${ }^{21)}$. The application of animal manures for increasing soil organic matter accomplished its mission. In present study, applications of other organic sources (rice and wood residues) not only increased organic matter but also decreased soil EC. The soil bulk density which was reduced by organic matter, improve the water permeability and promote mobility of salt ${ }^{222}$.

Soil tillage affects speeds of decomposition of soil organic matter and the release of mineral nutrients ${ }^{23}$. Nutrient dynamics under tillage and crop management practice vary from one ecological region to another and among diverse crop combinations ${ }^{17}$. Deeper plowing did not decrease soil organic matter, it might be due to applying large amounts of organic amendment. Deeper plowing had a negative effect on $\mathrm{Ca}$ content. Soil calcium content in 84 percent of Korea is in the deficit range for plant growth ${ }^{18)}$. However the Ca content of greenhouse top soil is high, but dramatically decreases downward into the subsoil ${ }^{22}$. Because Ca content is reduced by mixing top soil and subsoil, there may be an increased requirement for Ca fertilization when plowing is deeper than conventional tillage.

Crop rotations, reduced tillage, cover crops, fallow periods, and balanced fertilizer application can help maintain and restore soil fertility ${ }^{14}$. Soil nutrientconsidering fertilization and fertigation reduced soil EC. Fertigation improves nutrient efficiency more than fertilizing the whole soil surface ${ }^{25,26)}$. Therefore, 
practicing fertigation reduced the amount of fertilizer used and did not induce increment of soil EC.

Dynamic soil quality is strongly influenced by agronomic practices ${ }^{27}$. Gobeille et al. ${ }^{28)}$ analyzed statistically significant effects of soil management methods on each soil chemical property. Based on effects of each soil method, similar effects of each method on major and minor elements were analyzed by cluster analysis (Fig. 1 and 2). A cluster analysis of major elements showed deeper plowing and crop rotation with rice had different effects from other methods. It might be due to reduction of major elements in comparison with other methods. In a cluster analysis of minor elements, practicing crop rotation, application of animal manures, and application of rice residues were linked at a high Ward's distances. This result shows that each soil management method has different influences on minor element contents. Therefore, a combination of soil management methods which has different influences may enhance soil fertility. In agricultural systems, soil and crop management decisions affect soil quality, soil nutrient dynamics, and soil chemical properties ${ }^{3}$. Each soil management method has a similar or different effect on soil chemical properties. These results suggest the necessity to establish limits and standards according to the effects of soil management methods on soil chemical properties for economic soil practices.

\section{LITERATURE CITED}

1. Abawi, G. S. and Widmer, T. L. (2000) Impact of soil health management practices on soilborne pathogens, nematodes, and root diseases of vegetable crops, Appl. Soil Ecol. 15(1), 37-47.

2. Hyun, B. K., Kim, L. Y., Kim, M. S., and Cho, H. J. (2001) Case study of good soil management in plastic film-house cultivation, Korean J. Soil Sci. Fert. 41(1), 26-33.

3. Mikha, M. M., Vigil, M. F., Liebig, M. A., Bowman, R. A., McConkey, B., Deibert, E. J., and Pikul, Jr. J. L. (2006) Cropping system influences on soil chemical properties and soil quality in the great plains, Agric. Food Syst. 21(1), 26-35.

4. Brejda, J. J., Moorman, T. B., Karlen, D. L., and Dao, T. H. (2000) Identification of regional soil quality factors and indicators I. Central and southern high plains, Soil Sci. Soc. Am. J. 64(6), 2115-2124.

5. Castrignano, A., Giugliarini, L., Risaliti, R., and Martinelli, N. (2000) Study of spatial relationships among some soil physico-chemical properties of a field in central Italy using multivariate geostatistics, Geoderma 97, 39-60.

6. NIAST (2000) Methods of soil chemical analysis. National Institute of Agricultural Science and Technology, Suwon, Korea.

7. Lee, Y. H., Lee, S. T., Lee, S. D., and Kim, Y. B. (2005) Chemical characteristics of soil and groundwater in plastic film house fields under fertigation system, Kor. J. Environ. Agric. 28(3), 233-237.

8. Ha, H. S., Yang, M. S., Lee, H., Lee, Y. B., Sohn, B. K., and Kang, U. G. (1997) Soil chemical properties and plant mineral contents in plastic film house in southern part of Korea, Korean J. Soil Sci. Fert. 30(3), 272-279.

9. Zhao, G. X., Li, X. J., Wang, R. Y., Li, T., and Yue, Y. D. (2007) Soil nutrients in intensive agricultural areas with different land-use types in Qingzhou county, China, Pedosphere 17(2), 165-171.

10. Bozkurt, S., Agca, N., and Odemis, B. (2008) Influence of different nitrogen sources and leaching practices on soil chemical properties under tomato vegetation in a greenhouse, J. Agron. 7(3), 210-219.

11. Lee, Y. H., Shin, Y. K., Hwang, K. N., and Rhee, G. S. (1993) Studies on chemical properties of soils under the plastic house cultivation of vegetables, Korean J. Soil Sci. Fert. 26(4), 236-240.

12. Motavalli, P. P. and Miles, R. J. (2002) Soil phosphorus fractions after 111 years of animal manure and fertilizer applications, Biol. Fertil. Soils 36(1), 35-42.

13. Hansen, S. (1996) Effects of manure treatment and soil compaction on plant production of a dairy farm system converting to organic farming practice, Agr. Ecosyst. Environ. 56(3), 173-186.

14. Tilman, D., Cassman, K. G., Matson, P. A., Naylor, R., and Polasky, S. (2002) Agricultural sustainability and intensive production practices, Nature 418, 671-677.

15. Deiana, S., Palma, A., Premoli, A., and Senette, C. (2007) Possible role of the polyuronic components in accumulation and mobilization of iron and phosphate at the soil root interface, Plant Physiol. Biochem. 45(5), 341-349.

16. Hao, X. and Chang, C. (2003) Does long-term heavy 
cattle manure application increase salinity of a clay loam soil in semi-arid southern Alberta?, Agric. Ecosyst. Environ. 94(1), 89-103.

17. DeMaria, I. C., Nnabude, P. C., and de Castro, O. M. (1999) Long-term tillage and crop rotation effects on soil chemical properties of a Rhodic Ferralsol in southern Brazil, Soil Tillage Res. 51(1-2), 71-79.

18. Yao, H., Jiao, X., and Wu, F. (2006) Effects of continuous cucumber cropping and alternative rotations under protected cultivation on soil microbial community diversity, Plant Soil 284(1), 195-203.

19. Martin-Rueda, I., Munoz-Guerra, L. M., Yunta, F., Esteban, E., Tenorio, J. L., and Lucena, J. J. (2007) Tillage and crop rotation effects on barley yield and soil nutrients on a Calciortidic Haploxeralf, Soil Tillage Res. 92, 1-9.

20. Xu, R. K., Coventry, D. R., Farhoodi, A., and Schultz, J. E. (2002) Soil acidification as influenced by crop rotations, stubble management, and application of nitrogenous fertiliser, Tarlee, South Australia, Aust. J. Soil. Res. 40(3), 483-496.

21. Cooperband, L. (2002) Building soil organic matter with organic amendments, Center for Integrated Agricultural Systems, University of Wisconsin-Madison, Wisconsin, USA, p.2.

22. Kim, P. J., Lee, D. K., and Chung, D. Y. (1997) Vertical distribution of bulk density and salts in a plastic film house soil, Korean J. Soil Sci. Fert.
30(3), 226-233.

23. Timsina, J., and Connor, D. J. (2001) Productivity and management of rice wheat cropping systems: issues and challenges, Field Crops Res. 69(2), 93-132.

24. Jung, B. G., Jeong, W. C., Yoon, J. H., Kim, Y. H., and Yun, E. S. (2001) Monitoring on chemical properties of bench marked upland soils in Korea, Korean J. Soil Sci. Fert. 34(5), 326-332.

25. Hebbar, S. S., Ramachandrappa, B. K., Nanjappa, H. V., and Prabhakar, M. (2004) Studies on NPK drip fertigation in field grown tomato (Lycopersicon esculentum Mill.), Eur. J. Agron. 21(1), 117-127.

26. Locascio, S. J., Hochmuth, G. J., Rhoads, F. M., Olson, S. M., Smajstrla, A. G., and Hanlon, E. A. (1997) Nitrogen and potassium application scheduling effects on drip-irrigated tomato yield and leaf tissue analysis, Hortscience 32(2), 230-235.

27. Carter, M. R. (2002) Soil quality for sustainable land management: Organic matter and aggregation interaction that maintain soil functions, Agron. jour. 94, 38-47.

28. Gobeille, A., Yavitt, J., Stalcup, P., and Valenzuela, A. (2006) Effects of soil management practices on soil fertility measurements on Agave tequilana plantations in western central Mexico, Soil Tillage Res. 87, 80-88. 